\title{
Fazendo as perguntas certas: os excluídos, o direito e a
}

\section{promoção do reconhecimento}

\author{
Wallace Corbo \\ Doutorando em Direito Público pela Universidade do Estado do Rio de Janeiro (UERJ). \\ Mestre em Direito Público pela UERJ. Professor Substituto de Direito Constitucional na \\ Faculdade Nacional de Direito (UFRJ). E-mail: wallacecorbo@gmail.com
}

\begin{abstract}
Resumo
O trabalho analisa o que denomino o problema das perguntas erradas: quando, deparados com casos que envolvem direitos fundamentais de minorias marginalizadas, intérpretes do Direito por vezes se voltam para aspectos irrelevantes ou pouco relevantes, formulando questionamentos e adotando perspectivas que acabam por perpetuar a discriminação histórica a que estão sujeitos estes grupos vulneráveis. Sustento, a partir dos trabalhos de Katherine T. Barlett e de Axel Honneth, a necessidade de se enfrentar o problema das perguntas erradas, em favor da promoção da inclusão e do reconhecimento destes grupos. Isto envolve, conforme concluo ao final, a necessidade de adotar três perspectivas na abordagem do Direito: pluralizar as instâncias jurídicas, de modo que sua composição apresente membros de minorias historicamente discriminadas; pluralizar o ensino jurídico, afastando-o de dogmáticas históricas e herméticas, em favor do debate sobre as perspectivas diversas que afetam grupos marginalizados; repensar, por fim, a própria metodologia do Direito, de modo a viabilizar a toda a comunidade de intérpretes do Direito o acesso a um instrumental teórico capaz de lidar com o problema da discriminação que afeta grupos vulneráveis.

Palavras-chave

Direito e Reconhecimento; Direito das Minorias; Interpretação; Direitos Fundamentais;

Direito Constitucional.
\end{abstract}

\section{Making the right questions: The excluded, Law and advancement of recognition}

\author{
Abstract

This article analyzes what I have called the problem of wrong questions: when confronted with cases involving fundamental rights of marginalized minorities, Law's interpreters have often turned to irrelevant or almost irrelevant aspects, presenting questions and 
perspectives that end up perpetuating the historical discrimination that affect vulnerable groups. I argue, following the works of Katherine T. Barlett and Axel Honneth, for the need of facing the problem with the wrong questions, in favor of promoting inclusion and recognition of these groups. This involves, in conclusion, the need to adopt three perspectives in dealing with the Law: the pluralization of legal agencies, in a way that their bodies include members of historically discriminated minorities; the pluralization of legal education, away from enclosed historical legal dogmatic, in favor of the debate on different perspectives that affect marginalized groups; rethinking, finally, legal method itself, so that all community of interpreters of the Law have access to theoretical tools that are able to deal with the problem of discrimination that affect vulnerable groups.

Keywords

Law and Recognition; Minorities Rights; Interpretation; Fundamental Rights; Constitutional Law.

\section{Sumário}

Introdução: perguntas erradas e o julgamento do recurso extraordinário n. 845.779. 1. Fazendo as perguntas certas: reflexões a partir da metodologia jurídica feminista de Katherine T. Barlett. 2. Por que fazer as perguntas certas? Reconhecimento, emancipação social e o Direito como uma esfera de reconhecimento. 3. Como pensar as perguntas certas? Emoções políticas e permeabilidade institucional. Conclusão.

\section{Introdução: perguntas erradas e o julgamento do recurso}

\section{extraordinário n. 845.779}

Em certa altura do julgamento do recurso extraordinário ("RE") n. 845.779 ${ }^{1}$, que trata do direito à auto-identificação de gênero de pessoas transexuais, o Ministro Luis Roberto Barroso proferia seu voto quando foi interrompido por um de seus colegas que, como que para arrematar o debate, lançou a seguinte pergunta: afinal, a parte recorrente "parece" mulher?² Na lógica que se desenvolveu por alguns minutos, bastaria analisar a foto da recorrente, uma mulher transexual, para, com facilidade, identificar se ela poderia ou não utilizar o banheiro feminino e, em sentido mais amplo, se ela teria direito a ser tratada como mulher.

O questionamento alterou substancialmente a discussão que se travava no Tribunal: até então, o ministro relator analisava aspectos concernentes ao direito à autonomia, ao direito à igualdade e à dignidade da pessoa humana de pessoas transexuais que são cotidianamente

\footnotetext{
${ }^{1}$ A íntegra da sessão pode ser encontrada em Youtube - Pleno - Suspenso julgamento que discute tratamento social dos transexuais. Disponível em < https://www.youtube.com/watch?v=t2nr57_Ku6c>. Acesso em 20 mar. 2017.

2 É curioso, no entanto, que este debate tenha sequer surgido entre os ministros, considerando o previsto no Enunciado n. 279 da Súmula do STF, que veda a reanálise do conjunto fático-probatório em sede de recurso extraordinário.
} 
marginalizadas e desrespeitadas em seus direitos mais básicos. A pergunta sobre a aparência da recorrente, no entanto, teve por efeito centrar a discussão em uma suposta relevância da aparência física da pessoa transexual como elemento de definição de seu gênero. Esta perspectiva, tradicional no tratamento (discriminatório) de pessoas transexuais, acabou pautando os minutos finais da sessão de julgamento, encerrada por pedido de vista do Ministro Luiz Fux.

O julgamento do RE n. 845.779 indicia uma preocupante característica que segue permeando os diversos órgãos jurídicos e instâncias judiciais: estamos fazendo as perguntas erradas. Por pergunta errada, refiro-me, em um sentido amplo, àquele tipo de questionamento que deveria ser considerado irrelevante ou pouco relevante para a solução de um problema jurídico. ${ }^{3}$ Em um sentido específico, que surge quando estão em jogo direitos fundamentais de minorias, perguntas erradas são aquelas que perpetuam ou viabilizam a manutenção de formas de discriminação e negação de direitos contra esses grupos. É neste sentido mais especifico que pretendo tratar do problema das perguntas erradas.

Neste artigo, argumento que a capacidade do ordenamento jurídico de proteger os direitos fundamentais de minorias está relacionada com a capacidade do Poder Judiciário e dos agentes jurídicos em geral de fazerem as perguntas certas. Estas perguntas são concebidas como certas na medida em que levem em consideração a posição das pessoas em situação de marginalização social, de modo a analisar de que forma o Direito pode servir como instrumento de emancipação e de promoção de reconhecimento.

Após estabelecer esta premissa, proponho que a formulação de perguntas certas é necessária para o atingimento de uma sociedade efetivamente emancipada e igualitária, no sentido proposto pelo ordenamento constitucional vigente. Neste sentido, é preciso avançar a pluralização e diversificação dos organismos jurídicos e judiciais no Brasil, o que demanda a adoção de mecanismos que tornem as instituições permeáveis aos grupos e demandas historicamente excluídos ou marginalizados em dada sociedade. Isto significa, (1) que o Poder Judiciário e as instituições jurídicas, incluindo as faculdades de Direito, devem ser capazes de incorporar, entre seus membros, indivíduos que pertençam aos grupos marginalizados; (2) que o ensino jurídico deve ser repensado para incorporar a perspectiva de grupos excluídos, permitindo que todos os intérpretes e aplicadores do Direito sejam convidados a refletir criticamente sobre as realidades, demandas e reivindicações destes grupos; (3) que se deve difundir, entre os atores jurídicos, um

\footnotetext{
${ }^{3}$ Neste sentido, fazer perguntas erradas é problemático em qualquer discussão jurídica. Não à toa, o Código de Processo Civil de 1973 exigia, em seu artigo 331, §3, que o juiz fixasse os pontos controvertidos da demanda. Fixar pontos controvertidos nada mais é do que apresentar, nos autos, as perguntas relevantes que merecem resposta. Curiosamente, o novo Código de Processo Civil suprimiu a exigência (talvez pela pouca adesão que o dispositivo revogado encontrou na jurisprudência) - o que não altera o fato de que, para dar a solução correta para questões jurídicas, é necessário saber que questões são essas.
} 
método que possibilite a formulação de perguntas certas quando se trata de direitos fundamentais de minorias

\section{Fazendo as perguntas certas: reflexões a partir da}

\section{metodologia jurídica feminista de Katherine T. Barlett}

É conhecido o pensamento de Ronald Dworkin, para quem, quando deparado com um caso de difícil solução, o juiz não está livre para decidir em qualquer sentido que se adeque à moldura normativa existente. Pelo contrário, nos casos difíceis, cabe ao julgador buscar a resposta certa à luz do ordenamento jurídico e de princípios morais. ${ }^{4}$ Por muito tempo temos, desde então, temos nos dedicado a buscar a resposta certa para casos difíceis. Esta preocupação pode surgir por detrás das discussões institucionais (supremacia judicial, supremacia legislativa, diálogos institucionais) ${ }^{5}$, das discussões sobre o papel da jurisdição constitucional (substancialismo e procedimentalismo) ${ }^{6}$, e de diversos debates no âmbito da teoria do direito (positivismo e pós-positivismo) ${ }^{7}$. Muitos livros, decisões e artigos procuraram a resposta certa, mas deixaram de lado uma questão crucial: qual é, afinal, a pergunta?

Definir as perguntas certas em um caso é relevante para qualquer processo decisório. É a partir da pergunta que são desvendados os fatos relevantes para a solução de um caso - e é a partir destes fatos que se descobre qual é o direito aplicável e, ao fim, qual é a solução correta. Sendo assim, uma pergunta inadequada, ou um olhar que foge das questões centrais é um problema que pode afetar diretamente a interpretação jurídica e a resposta dada a um litígio.

O problema das perguntas erradas é especialmente preocupante quando uma discussão jurídica envolve direitos de grupos e indivíduos submetidos à discriminação e marginalização históricas. Ou seja, quando os afetados são minorias sociais ${ }^{8}$ sujeitas a injustiças que vão desde a

\footnotetext{
${ }^{4}$ Entre os diversos escritos nos quais o autor desenvolveu esta ideia, confira-se especialmente DWORKIN, Ronald. Levando os direitos à sério. Tradução de Nelson Boeira. São Paulo: Martins Fontes, 2002, passim.

5 Sobre esta discussão, confira-se o trabalho de BRANDÃO, Rodrigo. Supremacia Judicial e Diálogos Constitucionais: a quem cabe a última palavra sobre o sentido da Constituição. Lumen Juris: Rio de Janeiro, 2012, passim.

${ }^{6}$ SOUZA NETO, Claudio. SARMENTO, Daniel. Direito Constitucional: Teoria, história e métodos de trabalho. Belo Horizonte: Fórum, 2012, p. 220-226.

7 O próprio Dworkin é representante deste debate, devendo-se destacar também a influência do trabalho de Robert Alexy (ALEXY, Robert. Teoria dos direitos fundamentais. Tradução de Virgílio Afonso da Silva. Malheiros: São Paulo, 2008, passim.)

${ }^{8}$ Apesar de o conceito de "minorias" ser comum no debate jurídico, é possível identificar ao menos três diversos significados que lhe podem ser atribuídos. Assim, o termo "minorias" pode ser abordado a partir de uma concepção numérica, de uma concepção procedimental e de uma concepção substantiva. A concepção numérica está associada à ideia de que minorias são grupos compostos por indivíduos que, numericamente, são menores que outros grupos - as maiorias. É a partir desta concepção que se fortalece, no contexto norteamericano, a ideia de que a Constituição promoveria um entrincheiramento dos direitos contra a atuação das 
violência física, passando pela privação de direitos e chegando à degradação de suas formas de vida. ${ }^{9} \mathrm{O}$ problema das perguntas erradas é especificamente pernicioso com relação a estes grupos porque, diferentemente dos equívocos que podem ocorrer em discussões envolvendo toda sorte de questão jurídica, nos casos que envolvem minorias (1) estas perguntas erradas são feitas cotidiana e reiteradamente, como reflexo de estruturas que discriminam e invisibilizam demandas destes grupos ${ }^{10}$; e (2) estas perguntas erradas conduzem à manutenção de um status quo de marginalização social.

Retome-se, neste sentido, a discussão trazida na introdução deste artigo, envolvendo o julgamento do RE n. 845.779. O recurso trata do direito à auto-identificação de gênero por pessoas transexuais - ou seja, o direito de pessoas transexuais a serem tratadas pelo gênero com o qual se identificam, independentemente do sexo que lhes foi atribuído no nascimento. $\mathrm{O}$ caso concreto envolve uma mulher transexual que foi impedida de usar o banheiro feminino de um shopping center. Como visto, o julgamento foi iniciado pelo voto do Ministro Roberto Barroso, que identificou e discutiu a marginalização e estigmatização históricas a que são submetidas as pessoas trans:

Os transexuais são uma das minorias mais marginalizadas e estigmatizadas na sociedade. (...) A incompreensão, o preconceito e a intolerância acompanham os transexuais durante toda a sua vida e em todos os meios de convívio social. (...) Atualmente, a transexualidade é considerada uma patologia, mas é preciso olhar o problema dos transexuais sob a perspectiva do direito ao

maiorias - o que conduziu à ideia de que o Poder Judiciário seria responsável pela proteção de minorias (GARGARELLA, Roberto. La justicia frente al gobierno: sobre el carácter contramayoritário del poder judicial. Barcelona: Ariel, 1996, p. 17-47). A concepção procedimental é aquela referenciada na Nota de Rodapé no 4 da opinião da Suprema Corte dos Estados Unidos no julgamento de United States v. Carolene Products. A concepção foi retomada por John $\mathrm{H}$. Ely na elaboração de sua teoria procedimentalista da jurisdição constitucional, e identifica como minorias aqueles grupos visíveis e insulares que são alvo de preconceito na sociedade (ELY, John Hart. Democracy and Distrust: A Theory of Judicial Review. 3. ed. Cambridge: Harvard University Press, 1980, p. 75 et seq). A terceira concepção, que denomino substantiva e que me parece mais adequada, considera minorias como grupos sociais em situação de vulnerabilidade, no sentido que estão sujeitos à opressão e dominação institucionais, conforme pensadas por Iris Marion Young (YOUNG, Iris Marion. Justice and the Politics of Difference. New Jersey: Princeton University Press, 1990, p. 33-65).

${ }^{9}$ Adoto, aqui, a classificação teórica de Axel Honneth, que analisa o problema da justiça a partir de padrões de reconhecimento recíproco envolvendo a integridade física que permite ao indivíduo desenvolver autoconfiança; a garantia de direitos, que permite atingir um autorrespeito; e a valorização solidária das formas de vida que confere a cada um a autoestima necessária para desenvolver seus projetos de vida (HONNETH, Axel. Luta por reconhecimento. Tradução de Luiz REPA. São Paulo: 34, 2003)

10 Para Iris Marion Young, as minorias sofrem os fenômenos da opressão e da dominação. A primeira consiste refere-se, de um lado, aos obstáculos institucionais que impedem que algumas pessoas aprendam, desenvolvam e empreguem habilidades em ambientes socialmente reconhecidos. De outro, significa também a existência de processos sociais institucionalizados que impedem que as pessoas desenvolvam as habilidades necessárias para a interação e comunicação com os outros e para a expressão de seus sentimentos em contextos sociais nos quais possam ser ouvidas. As condições sociais de opressão podem incluir a privação ou a má-distribuição material, mas também envolvem problemas além da distribuição (YOUNG, Iris Marion. Justice and the Politics of Difference. New Jersey: Princeton University Press, 1990, p. 31-38).

Revista Publicum

Rio de Janeiro, v. 3, n. 2, 2017, p. 78-105

http://www.e-publicacoes.uerj.br/index.php/publicum

DOI: 10.12957/publicum.2017.28826 
reconhecimento. (...) A verdade é que não se trata de uma doença, mas de uma condição pessoal, e, logo, não há que se falar em cura. ${ }^{11}$

Partindo desta premissa, o Ministro Relator avançou para analisar os aspectos concernentes ao princípio da dignidade da pessoa humana que permitiriam resolver o caso. Neste sentido, Barroso sustentou o "direito a ser quem se é", no sentido de que "deixar de reconhecer a um indivíduo a possibilidade de viver sua identidade de gênero em todos os seus desdobramentos é privá-lo de uma das dimensões que dão sentido à sua existência" ${ }^{12}$. O que os excertos das anotações do Ministro Barroso revelam, portanto, é uma preocupação, na condução do julgamento, com uma análise centrada na pessoa transexual - inclusive afirmando a prevalência do direito ao reconhecimento destas pessoas em comparação com o potencial incômodo gerado a terceiros. ${ }^{13}$ De que maneira, então, o debate mencionado no início deste artigo influenciou a discussão posta perante o STF? Na linha do que afirmei, o questionamento quanto à aparência da recorrente - ela "parecia mulher" ou não? - serve a consequências problemáticas. ${ }^{14}$ Em primeiro lugar, este tipo de questionamento resgata um tratamento discriminatório tradicionalmente conferido às pessoas transexuais. Indagar se alguém "parece mulher" implica transferir para terceiros o poder de identificar o gênero de uma pessoa - negando-lhe, assim, a autonomia e, mais importante, subtraindo-Ihe o protagonismo de sua própria vida.

Em segundo lugar, perguntas dessa espécie têm por consequência conceber pessoas transexuais como permanentes fraudadores potenciais da lei. Em outras palavras, a pergunta pressupõe que pessoas se auto-identificam como transexuais buscando interesses escusos (como ingressar no banheiro de um sexo diverso do seu). Consequentemente, a pergunta acaba criando verdadeira espécie de presunção relativa de fraude, impondo às pessoas trans o dever de constantemente comprovar sua transexualidade. ${ }^{15}$

${ }^{11}$ STF. Recurso Extraordinário n. 845.779. Anotações para o voto oral do Ministro Luís Roberto Barroso. Disponível em < https://jota.info/docs/leia-a-integra-dos-argumentos-do-ministro-barroso-no-julgamentosobre-transexuais-19112015 >. Acesso em 16 mai. 2017.

12 STF. Recurso Extraordinário n. 845.779. Anotações para o voto oral do Ministro Luís Roberto Barroso. Disponível em <https://jota.info/docs/leia-a-integra-dos-argumentos-do-ministro-barroso-no-julgamentosobre-transexuais-19112015 >. Acesso em 16 mai. 2017.

${ }^{13}$ Nas palavras de Barroso, "a mera presença de transexual feminina em áreas comuns de banheiro feminino, ainda que gere algum desconforto, não é comparável àquele suportado pela transexual em um banheiro masculino" (STF. Recurso Extraordinário n. 845.779. Anotações para o voto oral do Ministro Luís Roberto Barroso. Disponível em <https://jota.info/docs/leia-a-integra-dos-argumentos-do-ministro-barroso-nojulgamento-sobre-transexuais-19112015>. Acesso em 16 mai. 2017.).

14 Os argumentos aqui identificados foram apresentados no âmbito do recurso extraordinário em petição apresentada pela Clínica de Direitos Fundamentais da UERJ, representando os amici curiae Centro LatinoAmericano em Sexualidade e Direitos Humanos (CLAM) e Laboratório Integrado em Diversidade Sexual e de Gênero, Políticas e Direitos (LIDIS).

${ }^{15}$ Esta observação foi também identificada por Lucas Freire ao tratar do longo e burocrático processo de alteração registral a que são sujeitas pessoas transexuais. Relatando as experiências do Núcleo de Defesa da Diversidade Sexual e Direitos Homoafetivos (NUDIVERSIS) da Defensoria Pública Geral do Estado do Rio de

Revista Publicum

Rio de Janeiro, v. 3, n. 2, 2017, p. 78-105

http://www.e-publicacoes.uerj.br/index.php/publicum

DOI: 10.12957/publicum.2017.28826 
Em terceiro lugar, esse tipo de questionamento surge em conjunto com uma alegada preocupação com a proteção de terceiros. No caso específico do RE n. 845.779, falava-se na "proteção" de mulheres e crianças contra homens que falsamente se declarassem mulheres transexuais e buscassem usar o banheiro feminino. $\mathrm{O}$ argumento não se resume à discussão sobre acesso a banheiro, mas também se aplica à discussão sobre alteração de nome e sexo no registro público - obstaculizadas tradicionalmente sob o fundamento de garantir a veracidade dos documentos públicos e a proteção de terceiros que poderiam ser "enganados" pelas informações que refletissem o gênero de pessoas trans. ${ }^{16}$

Deve-se notar, contudo, que o subterfúgio da "proteção de terceiros" exerce uma função primordialmente retórica - os terceiros supostamente afetados não são ouvidos ${ }^{17}$ e análises sobre os impactos de uma decisão sobre estes não são efetivamente considerados. Em realidade, o "terceiro" acaba funcionamento como mera representação retórica dos temores morais do intérprete.

Estas objeções ao reconhecimento de pessoas trans refletem, assim, os dois problemas associados à formulação de perguntas erradas: reforça-se o tratamento histórico avesso ao avanço de direitos de grupos marginalizados e perpetua-se esse status quo de discriminação, na medida em que as minorias afetadas são efetivamente retiradas do centro do debate em favor de outras preocupações - como o interesse público, os direitos de terceiros, a veracidade dos documentos.

Se for possível, no entanto, identificar no direito um caráter emancipatório ${ }^{18}$, é necessário buscar mecanismos capazes de enfrentar o problema das perguntas erradas, evitando que elas continuem sendo formuladas e priorizadas, de modo a permitir, assim, a inclusão progressiva dos grupos marginalizados. A esta altura e como primeiro passo desta empreitada, torna-se necessário

Janeiro (DPGE-RJ), o autor sustenta que a exigência de uma série de documentos que comprovem que uma pessoa é um "verdadeiro transexual" revela uma desconfiança institucional e social com relação às pessoas trans que o autor traduzida na ideia de uma "lógica de suspeição". Segundo o autor, "tal lógica de suspeição se torna evidente quando as profissionais do núcleo afirmam que os documentos requisitados funcionam como provas para afastar a constante suspeita de que as pessoas solicitam a alteração do registro civil para escapar de julgamento e/ou condenação por conta de algum crime, dívida etc". Neste sentido, o processo de alteração de nome e sexo deixa de ser concebido como uma forma de superar a marginalização a que estão submetidas estas pessoas, e passa a ser pensado como um instrumento potencial de fraude, utilizado por potenciais fraudadores (FREIRE, Lucas. Sujeitos de papel: sobre a materialização de pessoas transexuais e a regulação do acesso a direitos. Cadernos Pagu, n. 48, Campinas, 2016).

16 O subterfúgio da "proteção a terceiros" não é empregado para obstar direitos de pessoas trans. Em discussões sobre igualdade de gênero, podem surgir argumentos em favor da família ou das crianças (cuja criação a sociedade tradicionalmente impõe às mulheres). Em discussões sobre direitos de casais homoafetivos, igualmente o argumento da proteção às crianças (sustentado para impedir a conscientização social e também para vedar o direito à adoção) é recorrente. Agradeço a Daniel Cardinali por chamar atenção a este fato.

${ }^{17}$ Note-se, por exemplo, que não foram nenhumas das duas ministras mulheres da Corte que suscitaram a discussão sobre o risco do reconhecimento do direito às pessoas transexuais.

18 Desenvolverei esta ideia a seguir, a partir da teoria do reconhecimento formulada por Axel Honneth. 
diferenciar, no contexto de litígios sobre direitos fundamentais de minorias, "perguntas erradas" de "perguntas certas". Para isso, auxilia-nos o quadro teórico traçado por Katherine T. Barlett em seu artigo Feminist Legal Methods. ${ }^{19}$ Partindo da crítica feminista ao direito como uma série de regras que perpetuam um cenário de discriminação contra mulheres, a professora da Faculdade de Direito de Duke buscou estabelecer uma metodologia jurídica feminista que, se empregada, poderia transformar o direito em uma ferramenta de combate a este mesmo cenário. ${ }^{20}$

Para a autora, esta metodologia envolve três métodos específicos: (i) fazer a pergunta feminina (making the woman question), (ii) empregar a razão prática feminista (feminist practical reasoning) e (iii) conscientizar sobre experiências coletivas de opressão (counsciouness-raising). Segundo Barlett, estes métodos são capazes de revelar aspectos do ordenamento jurídico que métodos tradicionais de aplicação do Direito suprimem ou deixam de perceber.

O primeiro método diz respeito à necessidade de refletir sobre as implicações negativas relacionadas a gênero que certas regras ou práticas aparentemente neutras podem produzir. ${ }^{21}$ Isso envolve questionar se as mulheres foram desconsideradas, como essa omissão pode ser corrigida e que diferença esta correção pode fazer. Nas palavras da autora,

\footnotetext{
"esta pergunta presume que algumas características do direito podem não só ser não-neutras em um sentido geral, como também 'masculinas' em um sentido específico. O objetivo da pergunta feminina é expor estas características e como elas operam, e sugerir como elas podem ser corrigidas". 22
}

A pergunta feminina é assim, para Barlett, um método de crítica necessário à análise jurídica, na medida em que é capaz de revelar como as estruturas sociais implicitamente tratam mulheres como diferentes e subordinadas. Isto não significa, no entanto, que a pergunta feminina leve a uma resposta em favor das mulheres ${ }^{23}$ - ela exige, sim, que o julgador perceba e leve em consideração os preconceitos de gênero quando da tomada de sua decisão.

19 BARLETT, Katherine. Feminist Legal Methods. Harvard Law Review. v. 103, n. 4, fev. 1990, p. 829-888.

20 Não aprofundarei, neste texto, a crítica que a autora enfrenta quanto aos riscos de se confundir metodologia com substancia. Estou de acordo com a afirmação de Barlett no sentido de que há uma relação quase inevitável entre método e substância, de maneira que a tentativa de imputar um equívoco a uma metodologia, por exemplo, feminista, está associada a uma percepção equivocada de que haveria algo como um método neutro no âmbito da aplicação do Direito (BARLETT, Katherine. Feminist Legal Methods. Harvard Law Review. v. 103, n. 4, fev. 1990, p. 843-847).

${ }^{21} \mathrm{~A}$ ideia de que normas e práticas aparentemente neutras podem produzir impactos negativos substanciais sobre grupos vulneráveis tem sido abordada, no direito brasileiro a partir da ideia de discriminação indireta. Sobre o tema, confira-se: CORBO, Wallace. Por que não uma igualdade "para valer"?: reconhecimento, minorias e a vedação à discriminação indireta no brasil. (Dissertação de Mestrado). Programa de PósGraduação em Direito. Universidade do Estado do Rio de Janeiro, Rio de Janeiro, 2015.

22 BARLETT, Katherine. Feminist Legal Methods. Harvard Law Review. v. 103, n. 4, fev. 1990, p. 837.

${ }^{23}$ Idem, p. 846. 
Barlett não resume este primeiro aspecto de sua metodologia às questões de gênero. Com efeito, a autora percebeu que a questão feminina é, em suma, uma questão sobre exclusão - ou seja, trata-se de perguntas que, apesar de se voltarem para aspectos relacionados a gênero, buscam identificar as formas de exclusão e opressão que incidem especificamente em determinados casos. Em um sentido mais amplo, assim, a pergunta feminina pode ser concebida como a pergunta do excluído. Novamente, segundo a autora:

Estendida para além de esforços para identificar a opressão baseada exclusivamente em gênero, a pergunta feminina pode atingir formas de opressão invisibilizadas não apenas pelas estruturas dominantes do poder, como também pelos esforços de descobrir preconceitos apenas em favor de mulheres. ${ }^{24}$

Aplicado ao mencionado caso das pessoas trans, a ideia da pergunta do excluído impõe ao intérprete formular questões como: de que forma o princípio da imutabilidade do registro público afeta pessoas transexuais? Que consequências a negação do direito à auto-identificação de gênero, em um sentido mais amplo, gera sobre estas pessoas? Como este reconhecimento poderia mudar a vida deste grupo em termos de fruição de direitos e participação democrática? São perguntas que não impedem, vale notar, questionamentos que possam dar peso a outras considerações. No entanto, ao serem formuladas, estas perguntas tornam necessária a reflexão sobre uma discriminação que poderia passar despercebida pela dogmática tradicional.

Um segundo método proposto pela autora é o emprego da razão prática feminista (feminist pratical reasoning). Este método consiste, segundo Barlett, em resistir a análises de princípios gerais e universais quando da solução de questões jurídicas, dando peso à análise contextual permitindo, dessa forma, identificar os dilemas da vida real que outras formas de racionalidade poderiam ignorar. É eloquente o exemplo dado pela autora sobre a aplicação deste método:

A questão do acesso ao aborto por menores exemplifica o potencial generativo e educador de fatos específicos. O princípio abstrato da autonomia familiar parece justificar logicamente uma lei estadual exigindo que menores obtenham o consentimento de seus pais antes de fazer um aborto. Menores são imaturas e pais e mães são indivíduos geralmente melhor situados para ajudá-las a tomar uma decisão tão difícil quanto fazer um aborto. Considerações reais sobre as circunstâncias dolorosas em que uma menor queira evitar notificar seus pais de sua decisão de fazer um aborto, no entanto, demonstram as dificuldades práticas dessa questão. ${ }^{25}$

${ }^{24}$ BARLETT, Katherine. Feminist Legal Methods. Harvard Law Review. v. 103, n. 4, fev. 1990, p. 848.

25 Idem, p. 852. 
Longe de desconsiderar as regras jurídicas existentes, o que a autora propõe é que as regras deixam espaço para novas percepções e perspectivas que são geradas por novos contextos, de modo que uma análise das circunstâncias de cada caso pode revelar outras formas não-antecipadas de aplicar e interpretar uma norma jurídica. ${ }^{26} \mathrm{Em}$ uma leitura especificamente feminista, a razão prática permite identificar - ao lado da pergunta feminina - novos aspectos relacionados a gênero que surgem em um caso; aspectos estes que um método meramente dedutivo ou abstrato não permitiria encontrar ${ }^{27}$. Assim, por exemplo, a razão prática feminista daria muito mais peso a perspectiva da mulher que sofre um estupro em seu casamento (levando em conta, por exemplo, um histórico específico de violência praticada pelo marido contra a vítima) do que eventuais perspectivas trazidas por seu marido (como a antiga defesa baseada na impossibilidade jurídica de estupro entre pessoas casadas, ou outras supostas "justificativas" para o estupro). Apesar de a autora não explorar este aspecto, também parece ser plenamente possível compreender a razão prática feminista em um sentido mais amplo como a razão prática do excluído - ou seja, um método de análise de casos que não considera apenas os princípios abstratos, mas também as particularidades concretas dos casos, dando necessário peso à experiência dos grupos excluídos afetados negativamente.

O RE n. 845.779 novamente exemplifica como uma razão prática do excluído poderia ter servido à superação de discriminações históricas perpetradas contra pessoas trans. Com efeito, não é possível decidir adequadamente questão tão sensível olhando-se apenas para princípios abstratos como o princípio da veracidade do registro público, ou o princípio da imutabilidade do registro público. Casos que envolvem direitos fundamentais de minorias tem especificidades próprias que se revelam de acordo com a forma de discriminação que cada grupo sofre. No caso de pessoas trans, é essencial olhar para os dados que apontam que o Brasil é um dos líderes quando se trata de rankings atestando a violência contra transexuais e travestis. ${ }^{28}$ Há quem estime que a expectativa de vida dessa população é baixíssima, sendo igualmente inexpressivos os índices de acesso, por parte destas pessoas, a serviços públicos como saúde e educação, bem como ao mercado de trabalho. ${ }^{29}$ Qualquer solução jurídica que se pretenda dar à discussão sobre direito à

${ }^{26}$ BARLETT, Katherine. Feminist Legal Methods. Harvard Law Review. v. 103, n. 4, fev. 1990, p. 853.

27 Idem, p. 856.

28 O Projeto de Monitoramento de Assassinatos Trans (Trans Murder Monitoring - TMM - Project) coloca o Brasil na infeliz liderança do ranking de países com maior número de assassinatos de pessoas trans entre 2008 e 2014. Disponível em: <http://tgeu.org/> Acesso em: 20 mar 2017.

${ }^{29}$ De acordo com a Associação Nacional de Travestis e Transexuais (Antra), a proporção de transexuais e travestis que trabalham com prostituição, em muito por falta de alternativa profissional, atinge $90 \%$ da população que integra este grupo. Disponível em: <http://www.cartacapital.com.br/blogs/feminismo-praque/o-preconceito-contra-transexuais-no-mercado-de-trabalho-2970.html> 
auto-identificação de gênero deve, portanto, lidar com esta realidade concreta - afinal, que consequências se pretende produzir: a manutenção do status quo ou o combate a esta realidade?

Por fim, um terceiro método elencado pela autora envolve a conscientização quanto à opressão a que estão sujeitas as mulheres (counsciousness raising). Apesar de estar menos expressa e diretamente relacionada com a aplicação do Direito, Barlett sustenta que é esta conscientização que permite uma posterior tradução, para o direito, das experiências coletivas de opressão - gerando, inclusive, novos métodos feministas para a aplicação do direito (como a pergunta feminina e a razão prática feminista) ${ }^{30}$.

Apesar de voltar seu foco para uma análise feminista, as reflexões trazidas por Barlett são relevantes quando se trata do problema das perguntas erradas. Em realidade, tanto a pergunta feminina quanto a razão prática feminista se voltam precisamente contra este problema buscando revelar e dar peso a perspectivas invisíveis ou desconsideradas quando da interpretação e aplicação do direito. Seguindo esta ideia, uma pergunta pode ser considerada como errada, no contexto da interpretação e aplicação de direitos fundamentais, quando ela deixa de refletir sobre a posição do indivíduo ou grupo marginalizado e quando ela se volta para aspectos que são (ou deveriam ser) irrelevantes ou de pouca relevância para a solução de casos envolvendo essas pessoas.

Perguntas erradas são, portanto, aquelas que ignoram a posição do excluído - tanto com relação aos efeitos discriminatórios que uma dada norma ou interpretação pode gerar sobre minorias, quanto com relação aos aspectos concretos relevantes que afetam estes indivíduos. Assim, para solucionar um caso envolvendo pessoas pretas, mulheres e LGBT, a questão primordial não deve ser "e minha filha?", "e o resto da sociedade", "e eu?". Estas perguntas podem ser feitas, mas apenas quando se tenha em vista que é importante, nestes casos, dar uma tônica especial a questão "e eles, os outsiders?". Esta é, portanto, uma pergunta certa.

Identificar perguntas certas, no entanto, não diz nada sobre como garantir que sejam feitas. Em certo sentido, Barlett tentou preencher essa lacuna a partir da ideia de conscientização. Significa que é com a mobilização crescente dos grupos, tornando cada vez mais públicas as experiências coletivas de opressão, que perguntas certas começam a surgir, disseminam-se e, enfim, passam a ser feitas.

Partindo deste panorama, eu gostaria de explorar duas outras questões que Barlett não enfrentou. A primeira diz respeito ao fundamento substantivo (ou filosófico) que permite dizer que a pergunta do excluído e a razão prática do excluído geram perguntas certas. Em outras palavras:

n. 845.779. Disponível em $<$ http://www.luisrobertobarroso.com.br/wpcontent/uploads/2015/11/Transexuais-RE-845779-Anotacoes-para-o-voto.pdf>. Acesso em 20 mar 2017. ${ }^{30}$ BARLETT, Katherine. Feminist Legal Methods. Harvard Law Review. v. 103, n. 4, fev. 1990, p. 866.

Revista Publicum 
por que devemos nos indagar sobre os impactos que o Direito produz sobre determinados grupos e sobre a realidade discriminatória a que estão sujeitos? Uma segunda questão, de igual complexidade, é saber como possibilitar que estas perguntas certas poderão ser realmente feitas?

\section{Por que fazer as perguntas certas? Reconhecimento, emancipação social e o Direito como uma esfera de reconhecimento}

Como visto, Barlett dedica-se intensamente à análise acerca das perguntas erradas e da necessidade de superar-se uma metodologia jurídica que, na visão da autora, tenderia a reproduzir padrões de discriminação e opressão vigentes na sociedade. A autora não aprofunda, no entanto, as razões filosóficas pelas quais essa metodologia tradicional deve ser superada. Escrevendo a partir do feminismo, a autora assume a premissa de que a desigualdade de gênero e a opressão contra as mulheres é um dado danoso à sociedade. ${ }^{31}$ Seguindo minha proposta de ampliar o quadro teórico de Barlett para além do feminismo, no entanto, gostaria de propor uma leitura menos contextualizada para a própria ideia de que há perguntas certas que devem ser feitas pelo Poder Judiciário e por outros agentes jurídicos. Trata-se de uma leitura que parte das teorias do reconhecimento incorporadas pela literatura jurídica nas últimas décadas.

Em linhas gerais, as teorias do reconhecimento como formuladas por autores como Charles Taylor $^{32}$, Nancy Fraser ${ }^{33}$ e Axel Honneth ${ }^{34}$, propuseram que as pessoas, além de (ou mais que) bens materiais, dependem de alguma forma de reconhecimento de suas identidades, demandas ou pretensões, inclusive como condição para que se entenda uma sociedade como justa. Esta ideia, por si só, já permite indicar o porquê de ser necessário formular perguntas certas na análise de questões que tratam de direitos fundamentais: fazer perguntas erradas, da forma como conceituadas anteriormente, implica negar reconhecimento às pessoas situadas em determinadas posições de desvantagem e que compartilham experiencias próprias de vida - o que, por consequência, impede o atingimento de uma sociedade mais justa. ${ }^{35}$ É necessário, contudo,

${ }^{31}$ BARLETT, Katherine. Feminist Legal Methods. Harvard Law Review. v. 103, n. 4, fev. 1990, p.833-836.

32 TAYLOR, Charles. The Politics of Recognition. In: TAYLOR, Charles. Multiculturalism. New Jersey: Princeton University Press, 1994.

33 FRASER, Nancy. Da redistribuição ao reconhecimento? Dilemas da justiça na era pós-socialista. In: SOUZA, Jessé. Democracia hoje: novos desafios para a teoria democrática contemporânea. Tradução de Márcia PRATES. Brasília: UnB, 2001, p. 245-282.

${ }^{34}$ HONNETH, Axel. Luta por reconhecimento. Tradução de Luiz REPA. São Paulo: 34, 2003, passim.

${ }^{35}$ As perspectivas de cada um dos autores sobre o que fundamenta a promoção do reconhecimento e que tipo de exigência se extrai da própria ideia de reconhecimento são completamente distintas. Enquanto pra Taylor o reconhecimento é instrumental ao atingimento de um ideal de autenticidade (ou seja, de ser verdadeiro consigo mesmo), Fraser concebe reconhecimento como uma série de demandas de caráter 
explorar melhor esta ideia, de modo que se possa conceber, de um lado, o reconhecimento como algo necessário ao desenvolvimento individual e coletivo de uma sociedade e, de outro, as reivindicações por direitos fundamentais como um meio de luta por reconhecimento.

Uma análise deste tipo pode ser desenvolvida a partir da contribuição de Axel Honneth para o desenvolvimento das teorias do reconhecimento, especialmente a partir de seu Luta por Reconhecimento. Naquela obra, o autor buscou apresentar uma gramática dos conflitos sociais que permitisse explica-los à luz do instrumental metafísico hegeliano coordenado com a psicologia social de George Mead. ${ }^{36} \mathrm{Na}$ linha do sustentado por Honneth, para que uma pessoa possa buscar sua autorrealização individual, ela dependerá de obter autoconfiança - obtida quando tem respeitadas sua integridade física e necessidades básicas $-{ }^{37}$, autorrespeito - que se desenvolve quando se lhe assegura igualdade jurídica $-{ }^{38}$ e autoestima - que se concretiza quando suas formas de viver são respeitadas socialmente ${ }^{39}$. Cada uma destas qualidades é conquistada a partir de relações intersubjetivas específicas, que se desenvolvem respectivamente no âmbito das relações primárias (amigos e família), das relações jurídicas e das relações de solidariedade. ${ }^{40}$

Nem sempre estas relações de reconhecimento recíproco são, contudo, positivas. Pelo contrário, as relações de reconhecimento são por vezes conflituosas, conduzindo inclusive a

simbólico que se somam a reivindicações por bens materiais (que ela denomina demandas por redistribuição) como condições para o atingimento de uma sociedade em que se garante a igual participação de todos no processo coletivo de tomada de decisões. Para Honneth, como se verá adiante, contudo, o reconhecimento deve ser concebido como a base das lutas sociais - englobando toda sorte de demandas formuladas por indivíduos como condição para sua plena busca por autorrealização (TAYLOR, Charles. The Politics of Recognition. In: TAYLOR, Charles. Multiculturalism. New Jersey: Princeton University Press, 1994; TAYLOR, Charles. The Ethics of Authenticity. Cambridge: Harvard University, 1991; FRASER, Nancy. Da redistribuição ao reconhecimento? Dilemas da justiça na era pós-socialista. In: SOUZA, Jessé. Democracia hoje: novos desafios para a teoria democrática contemporânea. Tradução de Márcia PRATES. Brasília: UnB, 2001, p. 245-282; HONNETH, Axel. Luta por reconhecimento. Tradução de Luiz REPA. São Paulo: 34, 2003).

${ }^{36}$ HONNETH, Axel. Luta por reconhecimento. Tradução de Luiz REPA. São Paulo: 34, 2003, passim.

${ }^{37}$ Segundo Honneth, a autoconfiança é uma capacidade que se desenvolve na esfera do reconhecimento que ele identifica como o Amor. Trata-se de uma segurança em relação ao seu próprio corpo pela qual o indivíduo passa a se entender como sujeito cujas necessidades merecem ser atendidas (HONNETH, Axel. Luta por reconhecimento. Tradução de Luiz REPA. São Paulo: 34, 2003, p. 164 et seq).

38 A atitude do autorrespeito desenvolve na esfera do reconhecimento do Direito e se refere ao reconhecimento do indivíduo enquanto um ator moralmente autônomo, capaz, portanto, não só de fazer julgamentos morais como de anuir com as regras gerais vigentes e participar do processo de formação da vontade coletiva (HONNETH, Axel. Luta por reconhecimento. Tradução de Luiz REPA. São Paulo: 34, 2003, p. 195 et seq).

${ }^{39} \mathrm{~A}$ autoestima, que se desenvolve em uma terceira esfera do reconhecimento - a Solidariedade - consiste no que pode ser denominada uma autoconfiança ética, no sentido de que o indivíduo passa a ser capaz de ser respeitado em suas habilidades e formas de vida, compreendendo-as como valiosas para o projeto coletivo (HONNETH, Axel. Luta por reconhecimento. Tradução de Luiz REPA. São Paulo: 34, 2003, p. 210 et seq).

${ }^{40}$ HONNETH, Axel. Luta por reconhecimento. Tradução de Luiz REPA. São Paulo: 34, 2003, passim.

Revista Publicum

Rio de Janeiro, v. 3, n. 2, 2017, p. 78-105

http://www.e-publicacoes.uerj.br/index.php/publicum

DOI: 10.12957/publicum.2017.28826 
formas degeneradas de reconhecimento. ${ }^{41}$ Assim, uma mulher que sofre violência doméstica não desenvolve adequadamente a característica de autoconfiança - ou seja, não se sente segura quanto à sua integridade física e psíquica. Uma pessoa homossexual que tenha negado o seu direito, por exemplo, a adotar uma criança, não desenvolve autorrespeito - no sentido de que não consegue se conceber como uma pessoa moralmente autônoma e juridicamente dotada das mesmas faculdades que os demais membros da comunidade. Uma pessoa que professe uma religião afro-brasileira que sofre com estigmas sociais fortes que negam a validade desta crença, por sua vez, não desenvolve a autoestima - concebida, aqui, como a capacidade de conceber sua forma de vida não só como válida, mas também positiva para o desenvolvimento do projeto social.

Partindo desta perspectiva, Honneth sustenta que a negação de reconhecimento - seja pela violação do indivíduo, pela privação de direitos ou pela degradação social - dá ensejo a sentimentos de vergonha e de autodepreciação capazes de gerar a mobilização com vistas à superação do estado de desrespeito vigente. ${ }^{42}$ É neste contexto que podem surgir movimentos sociais, concebidos como movimentos organizados em torno de sentimentos comuns de vergonha social que buscam (re)estabelecer o reconhecimento negado - convertendo a vergonha em orgulho e organizando-se no sentido de expandir os horizontes de reconhecimento de uma dada sociedade. 43

Este panorama sintético do pensamento honnethiano já nos permite compreender por quê as perguntas erradas são erradas. Sendo verdadeiro que perguntas erradas perpetuam uma discriminação ou invisibilidade históricas, então a formulação destas perguntas gera, também, uma relevante negação de reconhecimento. Quando, por exemplo, o intérprete do direito indaga sobre como a forma de vida de uma determinada minoria impacta outros grupos - sem refletir sobre sua importância para este próprio grupo e seus integrantes -, então nega-se a condição daquelas pessoas enquanto seres humanos moralmente autônomos e dignos de igual respeito e consideração pelo Direito. Uma pergunta errada, portanto, está errada porque impede o atingimento de um objetivo de emancipação social - que só é possível a partir de uma postura crítica e reflexiva, que dê centralidade às reivindicações formuladas por grupos aos quais tradicionalmente se tem negado reconhecimento.

Há, ainda, uma segunda razão que justifica a necessidade de se fazer as perguntas certas. Trata-se do fato de o Direito ser uma especial esfera de reconhecimento, que permite avançar não

\footnotetext{
${ }^{41}$ Não é apenas Honneth que percebe a natureza conflituosa destas relações. Seguindo a mesma tradição hegeliana, Taylor chegou à mesma conclusão (TAYLOR, Charles. The Ethics of Authenticity. Cambridge: Harvard University, 1991, p. 46-48).

42 HONNETH, Axel. Luta por reconhecimento. Tradução de Luiz REPA. São Paulo: 34, 2003, p. 224.

${ }^{43}$ Reconhecendo o importante papel dos movimentos sociais na transformação da vergonha em orgulho, confira-se: BRITT, Lory; HEISE, David. From shame top ride in identity politics in STRYKER, Sheldon et al. Self, Identity and Social Movements. Minneapolis: University of Minnesota, 2000, p. 252-268.
} 
só na obtenção de autorrespeito (enquanto individuo moralmente autônomo), mas também de autoconfiança e de autoestima - ou seja, como indivíduos que entendem que sua integridade física e as formas de vida que adotam são socialmente respeitadas. Para compreender esta afirmação, é preciso retomar o papel do Direito na teoria do reconhecimento honnethiana. Como visto, o autor pensou o Direito como um espaço de reconhecimento da imputabilidade moral dos indivíduos que é regido pelo princípio da igualdade jurídica. Trata-se de uma esfera em que propriedades universais dos seres humanos são reconhecidas, conferindo-Ihes o autorrespeito com relação a sua capacidade de tomar decisões morais e de sujeitar-se às mesmas regras e fruir dos mesmos benefícios jurídicos que seus pares.

Assim como ocorre nas demais esferas do reconhecimento, as lutas por reconhecimento travadas por indivíduos e grupos em dada sociedade pressionam os limites do Direito no sentido de uma expansão que se dá em dois níveis: uma expansão social, pela qual indivíduos previamente excluídos passam a ser abrigados pela proteção jurídica; e uma expansão objetiva, por meio da qual novas demandas passam a ser resguardadas juridicamente como condição para o reconhecimento da autonomia moral das pessoas. ${ }^{44}$ Diferentemente das demais esferas de reconhecimento (a das relações primárias e a da estima social), no entanto, o Direito apresenta um potencial emancipatório único. Segundo Honneth, nas últimas passagens de seu Luta Por Reconhecimento:

os padrões de reconhecimento do direito penetram o domínio interno das relações primárias, porque o indivíduo precisa ser protegido do perigo de uma violência física, inscrito estruturalmente na balança precária de toda ligação emotiva (...). Mas a relação jurídica moderna influi sobre as condições da solidariedade pelo fato de estabelecer as limitações normativas a que deve estar submetida a formação de horizontes de valores fundadores da comunidade. ${ }^{45}$

Em outras palavras, a expansão do Direito pode estabelecer limites tanto nas esferas das relações primárias quanto da estima social, fixando proteções específicas capazes de fortalecer a pretensão de autorrealização dos indivíduos e grupos. Exemplo disso é a forma pela qual a Lei Maria da Penha buscou empoderar mulheres, em suas relações primárias, contra a gravíssima realidade da violência doméstica. ${ }^{46}$ Ou como a proteção constitucional a comunidades tradicionais e povos

\footnotetext{
${ }^{44}$ Esta expansão se desenvolve a partir do recurso ao princípio da igualdade jurídica, cf. HONNETH, Axel. Luta por reconhecimento. Tradução de Luiz REPA. São Paulo: 34, 2003, p. 193.

45 HONNETH, Axel. Luta por reconhecimento. Tradução de Luiz REPA. São Paulo: 34, 2003, p. 278.

46 Uma concepção do Direito assim posta é partidária, portanto, da ideia colocada pelos movimentos feministas de que o privado ou pessoal é político. Sobre a releitura feminista da dicotomia público-privado, confira-se PATEMAN, Carole. O contrato sexual. Tradução de Marta Avancini. São Paulo: Paz e Terra, 1993, passim.
} 
indígenas transfere para o Direito parte da função de estabelecer horizontes de valores compartilhados, contribuindo para a promoção de uma solidariedade social no sentido honnethiano. ${ }^{47}$

Neste sentido, enquanto a primeira razão para que sejam feitas as perguntas certas - ou seja, para que se voltem os olhos para a posição das minorias sociais e para os efeitos perniciosos que o Direito pode causar-Ihes - é a necessidade de se promover o reconhecimento dessas pessoas enquanto agentes autônomos, dando-Ihe voz como forma de garantir uma ampla emancipação social; o segundo fundamento para a realização destas perguntas é a percepção de que o Direito pode ocupar papel importante na promoção deste objetivo emancipatório. Não significa dizer que o Direito possa resolver todas as mazelas da sociedade, mas, sim, compreender que a garantia de direitos pode influenciar direta ou indiretamente outras esferas de reconhecimento, colaborando para uma sociedade mais inclusiva.

Até aqui, portanto, entendemos a distinção entre o que podem ser concebidas como perguntas certas e perguntas erradas e compreendemos por quê as perguntas certas, como as conceituamos, devem ser feitas. Falta, contudo, identificar mecanismos que possam fomentar a formulação destas perguntas certas. Isto envolve, em um sentido amplo, o desenvolvimento de certas habilidades e capacidades humanas e, em um sentido específico, uma organização institucional que seja capaz de incorporar diferentes olhares às instâncias judiciais. É esta perspectiva que pretendo aprofundar no item seguinte.

\section{Como pensar as perguntas certas? Emoções políticas e}

\section{permeabilidade institucional}

E o crack? A reflexão sobre esta droga foi trazida pelo ministro Gilmar Mendes logo após o voto do Ministro Luis Roberto Barroso no Recurso Extraordinário n. 635.659, em que este defendia a descriminalização do uso de drogas. ${ }^{48}$ Até então, Barroso sustentara que a criminalização do uso

\footnotetext{
${ }^{47}$ Não significa, contudo, que o recurso (e a necessidade de recurso) a este instrumental jurídico seja sem traumas. Por certo, mulheres que sofrem violência doméstica por vezes precisam superar obstáculos internos (psicológicos) e externos (sociais) para deflagrar o processo de proteção estatal. Ainda, o Direito não é capaz de apagar as violações pretéritas, ou impedir toda e qualquer violação futura. No entanto, a garantia de direitos permite incutir em uma determinada sociedade a confiança de que suas pretensões normativas estão protegidas, fomentando uma cultura de respeito que promove não só o reconhecimento jurídico como também, no caso da violência doméstica, a autoconfiança. Agradeço à professora Ana Paula de Barcellos por essa observação.

48 Trata-se do Recurso Extraordinário n. 635.659, de relatoria do Ministro Gilmar Mendes. A sessão de julgamento foi iniciada em 20.08.2015, e o voto do Ministro Roberto Barroso foi proferido no dia 10.09.2015, cuja sessão pode ser conferida no seguinte link: Youtube - Pleno - Julgamento sobre porte de drogas para consumo próprio. Disponível em <https://www.youtube.com/watch?v=d6z2/4TClQg>. Acesso em 20 mar. 2017.
} 
violava a autonomia pessoal, sendo injustificável à luz do ordenamento constitucional - sem prejuízo de manter-se a criminalização do tráfico desde que definida a quantidade de droga que diferencia a conduta de uso da conduta de tráfico. O caso concreto, no entanto, tratava do porte de maconha, do modo que o Ministro Gilmar Mendes, em seu aparte, acabou por provocar seu colega a refletir sobre outro entorpecente, de efeitos mais perniciosos que a cannabis. Para Barroso, o uso do crack poderia seguir criminalizado. ${ }^{49}$

Há algo de especialmente curioso na posição adotada, até o momento, por Luis Roberto Barroso, naquela sessão. De um lado, sabe-se que, tanto profissional quanto academicamente, o Ministro tem reiteradamente se posicionado em favor de teses que avançam direitos fundamentais de diversas minorias, como pessoas $\mathrm{LGBT}^{50}$ e mulheres ${ }^{51}$. De outro lado, contudo, ao indicar que tende a se posicionar pela manutenção da criminalização do crack - posição oposta à que prega com relação a maconha -, Barroso acaba por adotar uma postura avessa a um grupo especificamente marginalizado da população. Usuários de crack são, afinal, dependentes químicos de menor poder aquisitivo, muitos pretos, em situação de rua e sujeitos - também em razão disso - a toda sorte de violência física. ${ }^{52}$ Há, portanto, uma aparente contradição entre a trajetória do pensamento de Barroso e sua posição - que assumiu ser ainda irrefletida - sobre a criminalização do uso do crack. Lida sob uma perspectiva específica, esta aparente contradição pode revelar por que, muitas vezes, perguntas certas deixam de ser feitas pelo Judiciário.

O que há de comum, afinal, entre matérias como a descriminalização da maconha, a proteção de certos direitos de pessoas LGBT e o avanço das pautas feministas na sociedade? Podese dizer que nos três casos foram articulados, historicamente, discursos contrários às reivindicações formuladas por usuários, pessoas LGBT e mulheres de modo a situar estas pessoas em uma posição de inferioridade ${ }^{53}$ - uma efetiva negação de reconhecimento, portanto. Nas

${ }^{49} \mathrm{Em}$ entrevistas posteriores ao início do julgamento, o ministro reconheceu que não se aprofundou na questão do crack e, por isso, evitou estender seu voto àquele entorpecente (O Globo. 'Minha principal escolha é diminuir o poder do tráfico', diz ministro do STF. Disponível em <http://oglobo.globo.com/sociedade/minhaprincipal-escolha-diminuir-poder-do-trafico-diz-ministro-do-stf-20872440\#ixzz4bxZZ2sBC>. Acesso em 20 mar. 2017).

50 Como já mencionado, é dele o voto condutor do RE n. n. 845.779. Sobre a temática LGBT, o Ministro também escreveu artigos, a exemplo de BARROSO, Luis Roberto. Diferentes, mas iguais: o reconhecimento jurídico das relações homoafetivas no Brasil. Revista Diálogo Jurídico, Salvador, v. 16, Mai/Jun/Ago 2007.

${ }^{51}$ Foi Barroso o advogado responsável pelo ajuizamento da ADPF n. 54, que tratou da interrupção de gestação de fetos anencéfalos.

52 De se notar, contudo, que nos últimos anos cresceu o uso do crack por pessoas com maior poder aquisitivo, cf. DUAIBILI, Lígia Bonacim; RIBEIRO, Marcelo; LARANJEIRA, Ronaldo. Profile of cocaine and crack users in Brazil. Cad. Saúde Pública, vol.24 suppl.4 Rio de Janeiro, 2008; FREIRE, Suzana et al. Intensidade de uso de crack de acordo com a classe econômica de usuários internados na cidade de Porto Alegre/Brasil. J. bras. psiquiatr. vol.61 no.4 Rio de Janeiro, 2012.

53 Especificamente com relação às mulheres e pessoas LGBT, confira-se: SILVA, Cristina Telles de Araújo. Por um constitucionalismo feminista: reflexões sobre o direito à igualdade de gênero. (Dissertação de Mestrado). Programa de Pós-Graduação em Direito. Universidade do Estado do Rio de Janeiro, Rio de Janeiro, 2016; e

Revista Publicum

Rio de Janeiro, v. 3, n. 2, 2017, p. 78-105

http://www.e-publicacoes.uerj.br/index.php/publicum

DOI: 10.12957/publicum.2017.28826 
últimas décadas, no entanto, os indivíduos afetados por este tratamento institucional discriminatório organizaram-se por meio de movimentos sociais, apresentando e difundindo suas pautas na esfera pública e, em especial, no âmbito do debate acadêmico de elite. ${ }^{54} \mathrm{~A}$ despeito de estarmos ainda longe de solucionar os problemas que afetam estas e outras pautas, pode-se dizer que há, atualmente, uma compreensão muito mais esclarecida sobre as realidades de pessoas LGBT, mulheres e usuários de certas drogas, por exemplo, do que havia anos atrás. Deve ser considerado, neste contexto, que atores jurídicos - especialmente aqueles envoltos na academia, como é o caso do Ministro Barroso - sofrem influxos destes discursos, inclusive em seus meios sociais. ${ }^{55}$ Como bem indicou Barroso, quem, nas camadas médias e altas da sociedade, não conhece alguém que use maconha ${ }^{56}$ Estendendo a reflexão, quem, entre os setores de elite, não conhece, por exemplo, pessoas LGBT que, por viveram em círculos sociais com maior acesso à educação e bens materiais, deixam de estar sujeitas às mesmas formas de opressão que pessoas LGBT mais pobres? ${ }^{57}$

Quero dizer, com isso, que entre os diversos fatores que influenciam as decisões judiciais, ${ }^{58}$ um atua especialmente quando se trata de formular as perguntas certas: trata-se das experiências

CARDINALI, Daniel Carvalho. A judicialização dos direitos LGBT no STF: limites, possibilidades e consequências. (Dissertação de Mestrado). Programa de Pós-Graduação em Direito. Universidade do Estado do Rio de Janeiro, Rio de Janeiro, 2016.

54 Uma análise da relação entre movimentos sociais e constitucionalismo pode ser encontrada em GOMES, Juliana Cesario Alvim. Por um constitucionalismo difuso: cidadãos, movimentos sociais e o significado da Constituição. (Dissertação de Mestrado). Programa de Pós-Graduação em Direito. Universidade do Estado do Rio de Janeiro, Rio de Janeiro, 2014, passim.

55 Neste sentido, o próprio Barroso identificou os valores do juiz, suas relações com outros atores políticos e institucionais, a colegialidade e a opinião publica como alguns dos elementos que influenciam as decisões judiciais, para além da mera dogmática jurídica (BARROSO, Luis Roberto. Constituição, Democracia e Supremacia Judicial. Disponível em < http://www.luisrobertobarroso.com.br/wpcontent/themes/LRB/pdf/constituicao_democracia_e_supremacia_judi

cial.pdf>. Acesso em 20 mar 2017).

${ }^{56}$ Apenas a título exemplificativo, um estudo recente apontou que universitários brasileiros - uma elite intelectual e, via de regra, econômica - utilizam-se com frequência da maconha, quando comparados com a população em geral (26,9\% dos universitários, em comparação com o índice de $17 \%$ na população), cf. ECKSCHMIDT, Frederico; ANDRADE, Arthur G.; OLIVEIRA, Lúcio G. Comparação do uso de drogas entre universitários brasileiros, norte-americanos e jovens da população geral brasileira. Jornal Brasileiro De Psiquiatria, v.62, n.3, p. 199-207, 2013.

57 Neste sentido é a afirmação de Marsiaj, para quem "a classe social afeta as possibilidades de estabelecimento de relações homoafetivas e de redes homossociais, que são de suma importância para o desenvolvimento de uma auto-identificação como gay ou lésbica. Isto não quer dizer, é claro, que gays e lésbicas de classe mais baixa não tenham condições de encontrar e conhecer outras pessoas com uma orientação sexual semelhante ou não consigam estabelecer redes de contatos com outros homossexuais. No entanto, classe interfere neste processo de maneira significativa" (MARSIAJ, Juan P. P. Gays ricos e bichas pobres: desenvolvimento, desigualdade socioeconômica e homossexualidade no Brasil. Cadernos AEL, v.10, n.18/19, 2003, p. 139).

${ }^{58} \mathrm{E}$, especificamente no caso da descriminalização das drogas, não pretendo incidir, aqui, no equívoco de simplificar excessivamente a discussão. Por certo, a perspectiva de grupo é apenas um dos diversos fatores que influenciam o posicionamento dos ministros. Não há espaço, contudo, para avançar outras discussões sobre o tema. Agradeço à professora Ana Paula de Barcellos por esta observação.

Revista Publicum

Rio de Janeiro, v. 3, n. 2, 2017, p. 78-105

http://www.e-publicacoes.uerj.br/index.php/publicum

DOI: 10.12957/publicum.2017.28826 
pessoais dos julgadores, incluindo seu contexto social e os fluxos de informação a que têm acesso. ${ }^{59} \mathrm{Na}$ medida em que entram em contato com certos grupos de pessoas e ideias, juízes podem desenvolver uma certa forma de pensar um Outro como um igual, como uma pessoa cujo respeito merece sua atenção - como alguém que importa. Neste contexto, pode-se desenvolver uma certa compaixão pelo próximo. Refiro-me à compaixão, aqui, na forma como é desenvolvida por Martha Nussbaum - como uma emoção política a partir da qual um indivíduo pode olhar para o Outro e pensar que "esta pessoa conta para mim, ela está entre meus objetivos e projetos mais importantes"60.

O desenvolvimento deste tipo de capacidade emotiva com relação ao Outro é relevante no contexto de aplicação e interpretação de direitos fundamentais. Tratando-se aqui de relações de reconhecimento recíproco, a capacidade de pensar o outro como alguém importante - por parte do julgador - potencializa sua capacidade de indagar sobre seu sofrimento e sua situação. Reduzse, com isso, a dimensão conflitiva das relações intersubjetivas de reconhecimento, potencializando não só uma empatia - como capacidade de ver a partir dos olhos do outro ${ }^{61}$ como também um respeito real pelas experiências de desrespeito sofridas por aqueles que reivindicam direitos fundamentais.

Não quero dizer, com isso, que juízes não podem ter compaixão por usuários de crack, ou por prostitutas, ou por travestis ou por tantos outros invisíveis da sociedade. No entanto, a distância entre suas realidades e a desses atores sociais, associada à série de estigmas ${ }^{62}$ que o discurso predominante na sociedade atribui a estes e outros grupos são fatores relevante que dificultam pensar o valor do sofrimento destas pessoas - o impacto que a negação do reconhecimento produz sobre elas. E isso obstaculiza, por sua vez, a possibilidade de se fazer perguntas certas.

Ocorre que se estruturarmos a questão das perguntas certas sobre a compaixão, passamos à dificílima tarefa de ter que responder como ensinar compaixão a juízes, desembargadores e outros atores jurídicos. Ainda mais complexo seria pensar, filosoficamente, como justificar um

59 Cf. BARROSO, Luis Roberto. Constituição, Democracia e Supremacia Judicial. Disponível em < http://www.luisrobertobarroso.com.br/wpcontent/themes/LRB/pdf/constituicao_democracia_e_supremacia_judi cial.pdf>. Acesso em 20 mar 2017

60 NUSSBAUM, Martha C. Political Emotions: Why Love Matters for Justice. Cambridge: The Belknap Press of Harvard University Press, 2013, p. 144.

61 Idem, p. 145. Para Nussbaum, no entanto, a empatia é apenas um element que pode integrar a compaixão - mas é possível que a empatia sirva, também, a intuito sádicos, contrários a ideias de justiça.

62 Adoto, aqui, o conceito de estigma como uma atributo depreciativo a partir dos quais as pessoas podem ser categorizadas como um outro que, por alguma razão, não é merecedor de igual consideração e respeito - sendo, assim, excluído da relação social cotidiana. Neste sentido, confira-se GOFFMAN, Erving. Estigma: notas sobre a manipulação da identidade deteriorada. 4a. ed. Rio de Janeiro: LTC, 2013. 
ordenamento jurídico com base na compaixão individual dos aplicadores do Direito. ${ }^{63}$ Haveria outra forma de fomentar a formulação destas perguntas, sem a necessidade de ingressar neste tortuoso caminho do cultivo de emoções? Sustento que sim, a partir de uma ideia de permeabilidade ou porosidade das instituições.

Refiro-me, aqui, à capacidade de a organização de uma dada sociedade dar vazão às diversas demandas por reconhecimento, já postas ou não na esfera pública, que são formuladas em uma sociedade. Lembre-se, a este respeito, que a conquista de direitos advém, na leitura das teorias do reconhecimento, da organização de pessoas em torno de determinadas experiências de desrespeito - formando movimentos sociais -, de sua formulação da esfera pública e do embate político que pode conduzir a um avanço no sentido da emancipação social. ${ }^{64} \mathrm{~A}$ permeabilidade institucional atua na primeira e segunda etapas desta conquista de direitos, estabelecendo mecanismos que potencializam a visibilização destas experiências de discriminação e a formulação destas demandas na esfera pública. Como afirma Jane Reis, ao tratar especificamente do Poder Judiciário,

Normativamente o conceito de representação democrática do Judiciário deve funcionar como um fator que impõe transparência e permeabilidade. Uma Corte que pretenda ser representativa tem o ônus de se estar aberta de forma igualitária à sociedade civil, de ser institucionalmente porosa, de facilitar o acesso dos vulneráveis e de considerar todos os argumentos em jogo na formulação da decisão judicial. ${ }^{65}$

Sob este mesmo recorte, Juliana Cesário identifica entre o que denominou mecanismos de permeabilidade social das instituições ${ }^{66}$ instrumentos processuais de participação em instâncias jurídicas (como as audiências públicas e os amici curiae) ${ }^{67}$, e preocupações quanto à linguagem, acesso à informação e composição de instituições - também com uma atenção especial ao Poder Judiciário ${ }^{68}$.

${ }^{63}$ Sobre esta dificuldade que se volta para a dependência da compaixão individual, agradeço novamente às observações da professora Ana Paula de Barcellos.

${ }^{64}$ HONNETH, Axel. Luta por reconhecimento. Tradução de Luiz REPA. São Paulo: 34, 2003, p. 258 et seq

65 PEREIRA, Jane R. G. Representação democrática do Judiciário: reflexões preliminaries sobre os riscos e dilemas de uma ideia em ascensão. Revista Juris Poiesis, n. 17, 2014. Disponível em < https://works.bepress.com/janereis/5/>. Acesso em 20 mar. 2017, p. 13.

66 Trata-se de mecanismos que, Segundo a autora, permitem que as transformações sejam absorvidas pelas instituições (GOMES, Juliana Cesario Alvim. Por um constitucionalismo difuso: cidadãos, movimentos sociais e o significado da Constituição. (Dissertação de Mestrado). Programa de Pós-Graduação em Direito. Universidade do Estado do Rio de Janeiro, Rio de Janeiro, 2014, p. 73).

67 GOMES, Juliana Cesario Alvim. Por um constitucionalismo difuso: cidadãos, movimentos sociais e o significado da Constituição. (Dissertação de Mestrado). Programa de Pós-Graduação em Direito. Universidade do Estado do Rio de Janeiro, Rio de Janeiro, 2014, passim.

68 GOMES, Juliana Cesario Alvim. O Supremo Tribunal Federal em uma perspectiva de gênero: mérito, acesso, representatividade e discurso. Direito e Práxis. Vol. 07, n. 15, 2016, p. 652-676.

Revista Publicum

Rio de Janeiro, v. 3, n. 2, 2017, p. 78-105

http://www.e-publicacoes.uerj.br/index.php/publicum

DOI: 10.12957/publicum.2017.28826 
A análise da permeabilidade das instituições às reivindicações e grupos sociais não se encerra, no entanto, nas instituições jurídicas. Pode-se falar, assim, na permeabilidade social das instituições de ensino ${ }^{69}$; da permeabilidade de grupos que integram uma dada sociedade ${ }^{70}$ e da permeabilidade social de instituições políticas ${ }^{71}$.

Em um certo sentido, portanto, a permeabilidade institucional objetiva a conscientização proposta por Barlett - tida como a articulação e compartilhamento de experiências que podem se converter em agir político e em revelação sobre os déficits do Direito. ${ }^{72}$ Sob esta perspectiva, a ideia de fazer perguntas certas pode ser pensada à luz de três premissas: (1) as perguntas certas feitas pelas pessoas certas; (2) as perguntas certas aprendidas pelas pessoas certas; e (3) as perguntas certas feitas sob um método adequado. Explico.

Pessoas brancas têm dificuldade de diferenciar pessoas negras. ${ }^{73}$ Não é um problema consciente, e envolve complexos aspectos neurológicos e sociais. O fato é, no entanto, que estudos apontam que, para pessoas brancas, negros são todos iguais (ou substancialmente iguais). Mais do que apenas não conseguir distinguir pessoas que pertencem a outros grupos, estudo conduzido pela Universidade de Harvard por meio de seu Project Implicit revela que indivíduos podem, por vezes, associar pessoas que pertencem a outra raça, gênero ou nacionalidade a características degradantes, de maneira inconsciente (ex.: maior parcela de homens consideram mulheres menos aptas para profissões técnicas; maior parcela de pessoas brancas associam pessoas pretas a características negativas). ${ }^{74}$

Partindo destas afirmações, é possível pensar, em um primeiro momento, que as perguntas certas - em que o interlocutor dá um devido e igual peso à posição dos excluídos - podem ser mais formuladas quando as pessoas certas estejam na posição de fazê-las. Em outras palavras, é

\footnotetext{
69 Uma análise especificamente voltada para a educação e a permeabilidade das carreiras do ensino superior, confira-se: BARBOSA, Maria L. O.; SANTOS, Clarissa T. A permeabilidade social das carreiras do ensino superior. Caderno CRH. Salvador, v. 24, n. 63, p. 535-554, Set./Dez. 2011, p. 535-554.

70 A exemplo da análise acerca da permeabilidade social das elites - ou seja, dos grupos socialmente privilegiados - no Brasil (FERREIRA, Marcelo C. Permeável, ma non tropo? A mobilidade social em setores de elite, Brasil -1996. RBCS, vol. 16, n. 54, out./2001, 141-185).

${ }^{71}$ É o caso de estudos voltados para a análise da permeabilidade de partidos políticos (BOLOGNESI, Bruno; COSTA, Luiz D. Fronteiras sociais fortes e padrões organizacionais fracos? Seleção de candidatos e composição social nos principais partidos políticos brasileiros em 2010. Conexão Política, Teresina v. 4, n. 1, $43-63$, jan./jun. 2015).

${ }^{72 B A R L E T T, ~ K a t h e r i n e . ~ F e m i n i s t ~ L e g a l ~ M e t h o d s . ~ H a r v a r d ~ L a w ~ R e v i e w . ~ v . ~ 103, ~ n . ~ 4, ~ f e v . ~ 1990, ~ 864-867) . ~}$

${ }^{73}$ LUCAS, Heather D.; CHIAO, Joan Y.; PALLER, Ken A. Why some faces won't be remembered: brain potentials illuminate successful versus unsuccessful encoding for same-race and other-race faces. Front. Hum. Neurosci. 5:20, 2011. Disponível em < http://journal.frontiersin.org/article/10.3389/fnhum.2011.00020/full>. Acesso em 20 mar 2017; e VIZIOLI, Luca; ROUSSELET, Guillaume A.; CALDARA, Roberto. Neural repetition suppression to identity is abolished by other-race faces. Proceedings of the National Academy of Sciences of the United States of America. Vol. 107, n. 46, 2010. Disponível em < http://www.pnas.org/content/107/46/20081.abstract>. Acesso em 20 mar 2017.

${ }^{74}$ Disponível em <https://implicit.harvard.edu/implicit/>. Acesso em 20 mar 2017.
} 
necessário pluralizar a composição das diversas instituições jurídicas, de modo a permitir o ingresso cada vez mais abrangente de pessoas com vivências e perspectivas distintas especialmente integrantes de grupos marginalizados. Por instituições jurídicas, não quero dizer apenas o Poder Judiciário ${ }^{75}$ - capaz de aplicar e interpretar direitos fundamentais em casos concretos - e outros profissionais jurídicos - que podem articulá-los nas instâncias políticas e judiciais -, mas também as próprias faculdades de Direito. Estas últimas são responsáveis, afinal, pela formação dos profissionais do Direito e, em sua pós-graduação e por meio de seus pesquisadores, pela construção do conhecimento jurídico que servirá de base para decisões futuras.

A ideia de que as perguntas certas podem ser formuladas pelas pessoas certas está, por sua vez, intimamente ligada a uma concepção de representação tida por identitária. Trata-se da concepção, nas palavras de Jane Reis, segundo a qual "a representação é avaliada pela semelhança entre o representante e o representado" ${ }^{76}$, de modo que têm interesses em comum um com o outro, compartilhando experiências entre si. Longe de significar que apenas pessoas pretas podem refletir sobre questões afetas ao racismo, ou que apenas mulheres podem perceber o machismo que persiste na sociedade, esta ideia simplesmente propõe que as experiências pessoais de discriminação são muitas vezes comuns entre os membros de um grupo ${ }^{77}$, de modo que suas perspectivas, levadas à esfera institucional - seja no campo judicial, seja no acadêmico - permitem uma melhor reflexão sobre quais são as preocupações escondidas que devem ser tratadas em casos que versam sobre direitos fundamentais. É na ideia de perguntas certas feitas por pessoas certas que podemos situar as políticas de ação afirmativa ${ }^{78}$ - especificamente aquelas que buscam

75 Especificamente com relação ao Supremo Tribunal Federal, Juliana Cesário Alvim Gomes aponta como a desigualdade de gênero se revela não só na disparidade da representação na composição da Corte, como também na tônica dada aos processos de sabatina a que foram submetidas as ministras da Corte (GOMES, Juliana Cesario Alvim. O Supremo Tribunal Federal em uma perspectiva de gênero: mérito, acesso, representatividade e discurso. Direito e Práxis. Vol. 07, n. 15, 2016, p. 652-676).

${ }^{76}$ PEREIRA, Jane R. G. Representação democrática do Judiciário: reflexões preliminaries sobre os riscos e dilemas de uma ideia em ascensão. Revista Juris Poiesis, n. 17, 2014. Disponível em < https://works.bepress.com/janereis/5/>. Acesso em 20 mar. 2017.

77 É neste sentido o conceito de grupo social trabalhado por Owen Fiss, para quem há uma relação recíproca entre o grupo e os seus integrantes, no sentido de que a posição relativa de um determinado grupo social influencia a posição relativa de seus sujeitos e vice-versa. (FISS, Owen M. Groups and the Equal Protection Clause. Philosophy and Public Affairs, n. 5, 1976. 107-177). É neste sentido que se pode falar no compartilhamento das experiências de opressa.

${ }^{78}$ Estas medidas, que variam substancialmente em escopo e finalidades, buscam promover a equiparação efetiva, no campo material, entre indivíduos historicamente situados em situação de desigualdade, garantindo o acesso a direitos e às condições para a participação em sociedade. Trata-se, pois, de um remédio que busca, no longo prazo, promover alterações substanciais nas relações sociais e intersubjetivas, buscando superar as formas de discriminação existentes. A este respeito, confira-se: GOMES, Joaquim B. B. Ação afirmativa e princípio constitucional da igualdade: o Direito como instrumento de transformação social. A experiência dos EUA. Rio de Janeiro: Renovar, 2001, passim; IKAWA, Daniela. Ações afirmativas em universidades. Rio de Janeiro: Lumen Juris, 2008, passim; ALMEIDA, Luciana D. R. D. Ações afirmativas e a concretização do princípio da igualdade no direito brasileiro, Belo Horizonte, Fórum, 2011, passim; BRANCO,

Revista Publicum

Rio de Janeiro, v. 3, n. 2, 2017, p. 78-105

http://www.e-publicacoes.uerj.br/index.php/publicum

DOI: 10.12957/publicum.2017.28826 
garantir ou promover o acesso a cargos jurídicos ${ }^{79}$ e vagas nas universidades públicas para determinados grupos.

Em segundo lugar, e como já mencionei, pessoas certas não são apenas aquelas que estão sujeitas à opressão e discriminação na condição de produtores de conhecimento jurídico ou de agentes jurídicos relevantes. Uma perspectiva deste tipo, que Barlett denominou "epistemologia do ponto de vista" (standpoint epistemology) presume que apenas a "vítima" é capaz de falar sobre a vitimização ${ }^{80}$ - ignorando, contudo, que há uma série de perspectivas relevantes para entender o fenômeno da opressão e que diversos agentes podem contribuir com o projeto de superação deste cenário. ${ }^{81}$ É necessário reconhecer, então, que as perguntas certas também devem ser aprendidas pelas pessoas certas. Aqui, pessoas certas devem ser pensadas como quaisquer pessoas que venham a ser convidadas ou situadas em posições nas quais devem refletir sobre, interpretar ou aplicar o Direito. Tal análise deve dar especial atenção ao ensino jurídico, que deve ser repensado de modo a incorporar estas perguntas, fugindo dos dogmas centenários que, extremamente fixados em ideais de sujeitos abstratos de direito ${ }^{82}$, podem ignorar a situação de pessoas concretas, que sofrem com uma realidade perniciosa. ${ }^{83}$

Em um terceiro sentido, as perguntas certas devem ser feitas a partir de um método adequado. Com isso, retomo a ideia de Barlett, no sentido de que a formulação de perguntas certas depende de que os intérpretes e agentes jurídicos, deparando-se com casos que envolvam pessoas

Paulo G. G. Ação afirmativa e Direito Constitucional, Direito Público, n. 1, jul-ago-set. 2003, CLÈVE, Clémerson M. CLÈVE, C. M.; RECK, Melina B. As ações afirmativas e a efetivação do princípio constitucional da igualdade. Revista de Direito Administrativo \& Constitucional, ano 3, n. 11, jan./fev./mar. 2003, p. 32.

79 Exemplo de medida neste sentido é a Lei n. 12.990/2014 - a Lei de Cotas no serviço público -, cuja constitucionalidade é objeto de análise no âmbito da Ação Declaratória de Constitucionalidade n. 41.

80 "Apesar de as vítimas saberem algo sobre vitimização que as não-vítimas não sabem, vítimas não têm acesso exclusivo à verdade sobre a opressão. A posição de outros - co-vítimas, observadores passivos, até mesmo os vitimizadores - apresentam perspectivas de um conhecimento específico que aqueles que querem acabar com a opressão precisam entender" (BARLETT, Katherine. Feminist Legal Methods. Harvard Law Review. v. 103, n. 4, fev. 1990, p. 875).

81 "Uma última dificuldade com a epistemologia do ponto de vista é a política adversarial do tipo nós-eles que ela apresenta. (...) Essa posição adversarial dificulta a prática feminista. Ela impede a compreensão por possíveis amigos do feminismo e paralisa os potenciais simpatizantes [da causa]" (BARLETT, Katherine. Feminist Legal Methods. Harvard Law Review. v. 103, n. 4, fev. 1990, p. 876).

82 Não se pode ignorar que, em uma certa medida, o surgimento do sujeito abstrato de Direito caminha lado a lado com a promoção de um certo sentido de igualdade, na medida em que permite romper-se com os modelos tradicionais de sociedades estratificadas em que a posição social concreta de um indivíduo definia o regime jurídico a que se submetia. Quando se trata de minorias, no entanto, essa abstração pode esconder as graves desigualdades sociais que impedem um efetivo tratamento igualitário no Direito (CORBO, Wallace. Por que não uma igualdade "para valer"?: reconhecimento, minorias e a vedação à discriminação indireta no brasil. (Dissertação de Mestrado). Programa de Pós-Graduação em Direito. Universidade do Estado do Rio de Janeiro, Rio de Janeiro, 2015).

83 Uma ideia semelhante foi proposta por Juliana Cesário Alvim Gomes, ao afirmar a necessidade de desenvolver-se uma educação crítica - pensada a partir de autores como Paulo Freire (GOMES, Juliana Cesário Alvim. Por um constitucionalismo difuso: cidadãos, movimentos sociais e o significado da Constituição. (Dissertação de Mestrado). Programa de Pós-Graduação em Direito. Universidade do Estado do Rio de Janeiro, Rio de Janeiro, 2014, p. 119 et seq, p. 132).

Revista Publicum

Rio de Janeiro, v. 3, n. 2, 2017, p. 78-105

http://www.e-publicacoes.uerj.br/index.php/publicum

DOI: 10.12957/publicum.2017.28826 
sujeitas a diversas formas de discriminação, busquem ativamente refletir sobre como o Direito pode gerar, apesar de sua aparente neutralidade, impactos negativos sobre grupos marginalizados e como algumas particularidades de um caso concreto podem demandar uma interpretação adequada de certos princípios abstratos? Não só isso, um método adequado dependerá, também, de um processo que potencialize a formulação destas perguntas - o que significa dizer que o próprio direito processual deve estar aberto à participação de minorias quando seus direitos estejam em jogo. ${ }^{84}$

Como se vê, estas três ideais estão intrinsecamente relacionadas. A pluralização das instituições permite o desenvolvimento de um pensar e agir jurídico cujos olhos estão abertos a pessoas excluídas. A partir do momento em que esse conhecimento voltado para grupos marginalizados se difunde por meio do ensino jurídico, estudantes e agentes jurídicos passam a refletir e problematizar formas não antes pensadas de discriminação e mecanismos para sua superação. Isto, por sua vez, permite reforçar e aprofundar uma metodologia de aplicação do Direito cada vez mais capaz de revelar antigas invisibilidades e de garantir que independentemente de resultados substantivos - as perguntas certas serão feitas.

\section{Conclusão}

Não foi meu objetivo tratar, nesta oportunidade, dos diversos meios, em contextos variados, pelos quais será possível avançar mecanismos específicos que potencializam a formulação do que denominei perguntas certas. Em realidade, o foco deste estudo é anterior a este (necessário) tema. Tratei, aqui, de apresentar os fundamentos que indicam a existência de um problema, as razões e as diretrizes para superá-lo. Este artigo é centrado, de fato, em perguntas, e não em respostas. Feitas estas ressalvas, três conclusões podem ser extraídas deste trabalho.

A primeira conclusão é a de que as instâncias jurídicas - incluindo aí não só o Judiciário, como os demais órgãos e entidades incumbidas de interpretar e aplicar o Direito - por vezes incidem no problema de formular perguntas erradas quando tratam de direitos de minorias. Ou seja, ao analisar casos envolvendo grupos vulneráveis, diversos atores jurídicos negligenciam aspectos relevantes sobre a discriminação e marginalização destes grupos, impedindo ou dificultando um avanço efetivo no sentido da emancipação social e de um projeto igualitário de sociedade. Isto não ocorre deliberadamente, nem com um intuito discriminatório específico. Pelo

\footnotetext{
${ }^{84}$ Ao refletir sobre os mecanismos para tornar a tutela de direitos fundamentais prioritária no Judiciário, Jane Reis conclui que "o primeiro (...) é reconhecer e debater a dimensão política das normas processuais. As regras processuais que pavimentam o acesso ao Judiciário constituem um dos pilares da política de direitos humanos do país" (PEREIRA, Jane R. G. O Judiciário como impulsionador dos direitos fundamentais: entre fraquezas e possibilidades. Revista da Faculdade de Direito da UERJ, n. 29, jun. 2016. Disponível em < https://works.bepress.com/janereis/5/>. Acesso em 20 mar. 2017, p. 144.
} 
contrário, a formulação de perguntas erradas é consequência de uma estrutura social que marginaliza e torna invisíveis certos grupos sociais, impedindo que suas demandas, realidades e preocupações sejam levadas adequadamente à esfera pública e às instâncias formais. Disto conclui-se, em segundo lugar, pela necessidade de repensar estas estruturas jurídicas de modo a torna-las permeáveis a estes grupos. Isto porque, como visto, o Direito pode constituir relevante ferramenta de combate ao quadro de marginalização social que afeta minorias. Isto se dá, especialmente, na medida em que o Direito fixa determinados limites que promovem o respeito aos indivíduos em suas relações afetivas, em suas relações com o Estado e em suas relações com a sociedade. Dessa forma, o Direito pode contribuir para impulsionar demandas por reconhecimento e promover a emancipação social de minorias.

A partir destas duas conclusões, avancei para a formulação de três perspectivas que devem ser enfrentadas para reduzir o problema das perguntas erradas. Em primeiro lugar, é necessário tornar as instâncias jurídicas permeáveis às demandas e grupos sociais marginalizados, pluralizando sua composição de modo que os integrantes destes grupos estejam em posição de formular as perguntas certas. Em segundo lugar, é necessário, de modo mais geral, desenvolver um ensino jurídico que esteja em sintonia com o combate à discriminação e promoção de direitos de minorias. Por fim, para além das pessoas que deverão formular perguntas certas, é necessário pensar um método de interpretação e aplicação do Direito que viabilize a formulação destas perguntas - o que envolve tanto dogmática, quanto procedimento. Atingindo, então, a real capacidade de formular perguntas certas, aí sim estaremos mais preparados para, enfim, buscar as necessárias e urgentes respostas.

\section{Referências}

ALEXY, Roberto. Teoria dos direitos fundamentais. Tradução de Virgílio Afonso da Silva. Malheiros: São Paulo, 2008.

ALMEIDA, Luciana D. R. D. Ações afirmativas e a concretização do princípio da igualdade no direito brasileiro, Belo Horizonte, Fórum, 2011.

BARBOSA, Maria L. O.; SANTOS, Clarissa T. A permeabilidade social das carreiras do ensino superior. Caderno CRH. Salvador, v. 24, n. 63, p. 535-554, Set./Dez. 2011, p. 535-554.

BARLETT, Katherine. Feminist Legal Methods. Harvard Law Review. v. 103, n. 4, fev. 1990, p. 829888.

BARROSO, Luis Roberto. Constituição, Democracia e Supremacia Judicial. Disponível em < http://www.luisrobertobarroso.com.br/wp-

content/themes/LRB/pdf/constituicao_democracia_e_supremacia_judicial.pdf>. Acesso em 20 mar 2017. 
BARROSO, Luis Roberto. Diferentes, mas iguais: o reconhecimento jurídico das relações homoafetivas no Brasil. Revista Diálogo Jurídico, Salvador, v. 16, Mai/Jun/Ago 2007.

BOLOGNESI, Bruno; COSTA, Luiz D. Fronteiras sociais fortes e padrões organizacionais fracos? Seleção de candidatos e composição social nos principais partidos políticos brasileiros em 2010. Conexão Política, Teresina v. 4, n. 1, 43 - 63, jan./jun. 2015.

BRANCO, Paulo G. G. Ação afirmativa e Direito Constitucional, Direito Público, n. 1, jul-ago-set. 2003.

BRANDÃO, Rodrigo. Supremacia Judicial e Diálogos Constitucionais: a quem cabe a última palavra sobre o sentido da Constituição. Lumen Juris: Rio de Janeiro, 2012.

BRITT, Lory; HEISE, David. From shame top ride in identity politics in S. STRYKER et al. Self, Identity and Social Movements. Minneapolis: University of Minnesota, 2000.

CARDINALI, Daniel C. A judicialização dos direitos LGBT no STF: limites, possibilidades e consequências. (Dissertação de Mestrado). Programa de Pós-Graduação em Direito. Universidade do Estado do Rio de Janeiro, Rio de Janeiro, 2016.

CLÈVE, Clémerson M. CLÈVE, C. M.; RECK, Melina B. As ações afirmativas e a efetivação do princípio constitucional da igualdade. Revista de Direito Administrativo \& Constitucional, ano 3, n. 11, jan./fev./mar. 2003.

CORBO, Wallace. Por que não uma igualdade "para valer"?: reconhecimento, minorias e a vedação à discriminação indireta no brasil. (Dissertação de Mestrado). Programa de PósGraduação em Direito. Universidade do Estado do Rio de Janeiro, Rio de Janeiro, 2015.

DUAIBILI, Lígia Bonacim; RIBEIRO, Marcelo; LARANJEIRA, Ronaldo. Profile of cocaine and crack users in Brazil. Cad. Saúde Pública, vol.24 suppl.4 Rio de Janeiro, 2008.

DWORKIN, Ronald. Levando os direitos à sério. Tradução de Nelson Boeira. São Paulo: Martins Fontes, 2002.

ECKSCHMIDT, Frederico; ANDRADE, Arthur G.; OLIVEIRA, Lúcio G. Comparação do uso de drogas entre universitários brasileiros, norte-americanos e jovens da população geral brasileira. Jornal Brasileiro De Psiquiatria, v.62, n.3, p.199-207, 2013.

ELY, John H. Democracy and Distrust: A Theory of Judicial Review. 3. ed. Cambridge: Harvard University Press, 1980.

FERREIRA, Marcelo C. Permeável, ma non tropo? A mobilidade social em setores de elite, Brasil 1996. RBCS, vol. 16, n. 54, out./2001, 141-185.

FISS, Owen M. Groups and the Equal Protection Clause. Philosophy and Public Affairs, n. 5, 1976. 107-177.

FRASER, Nancy. Da redistribuição ao reconhecimento? Dilemas da justiça na era pós-socialista. In: SOUZA, J. Democracia hoje: novos desafios para a teoria democrática contemporânea. Tradução de Márcia PRATES. Brasília: UnB, 2001, p. 245-282.

FREIRE, Lucas. Sujeitos de papel: sobre a materialização de pessoas transexuais e a regulação do acesso a direitos. Cadernos Pagu, n. 48, Campinas, 2016 
FREIRE, Suzana et al. Intensidade de uso de crack de acordo com a classe econômica de usuários internados na cidade de Porto Alegre/Brasil. J. bras. psiquiatr. vol.61 no.4 Rio de Janeiro, 2012.

GARGARELLA, Roberto. La justicia frente al gobierno: sobre el carácter contramayoritário del poder judicial. Barcelona: Ariel, 1996.

GOFFMAN, Erving. Estigma: notas sobre a manipulação da identidade deteriorada. 4a. ed. Rio de Janeiro: LTC, 2013.

GOMES, Joaquim B. B. Ação afirmativa e princípio constitucional da igualdade: o Direito como instrumento de transformação social. A experiência dos EUA. Rio de Janeiro: Renovar, 2001.

GOMES, Juliana Cesario. Por um constitucionalismo difuso: cidadãos, movimentos sociais e o significado da Constituição. (Dissertação de Mestrado). Programa de Pós-Graduação em Direito. Universidade do Estado do Rio de Janeiro, Rio de Janeiro, 2014.

O Supremo Tribunal Federal em uma perspectiva de gênero: mérito, acesso, representatividade e discurso. Direito e Práxis. Vol. 07, n. 15, 2016, p. 652-676

HONNETH, Axel. Luta por reconhecimento. Tradução de Luiz REPA. São Paulo: 34, 2003.

IKAWA, Daniela. Ações afirmativas em universidades. Rio de Janeiro: Lumen Juris, 2008.

LUCAS, Heather D.; CHIAO, Joan Y.; PALLER, Ken A. Why some faces won't be remembered: brain potentials illuminate successful versus unsuccessful encoding for same-race and other-race faces. Front. Hum. Neurosci. 5:20, 2011. Disponível em <

http://journal.frontiersin.org/article/10.3389/fnhum.2011.00020/full>. Acesso em 20 mar 2017.

MARSIAJ, Juan P. P. Gays ricos e bichas pobres: desenvolvimento, desigualdade socioeconômica e homossexualidade no Brasil. Cadernos AEL, v.10, n.18/19, 2003.

NUSSBAUM, Martha C. Political Emotions: Why Love Matters for Justice. Cambridge: The Belknap Press of Harvard University Press, 2013.

PATEMAN, Carole. O contrato sexual. Tradução de Marta Avancini. São Paulo: Paz e Terra, 1993.

PEREIRA, Jane R. G. Representação democrática do Judiciário: reflexões preliminaries sobre os riscos e dilemas de uma ideia em ascensão. Revista Juris Poiesis, n. 17, 2014. Disponível em < https://works.bepress.com/janereis/5/>. Acesso em 20 mar. 2017.

O Judiciário como impulsionador dos direitos fundamentais: entre fraquezas e possibilidades. Revista da Faculdade de Direito da UERJ, n. 29, jun. 2016. Disponível em < https://works.bepress.com/janereis/5/>. Acesso em 20 mar. 2017.

SILVA, Cristina Telles de Araújo Por um constitucionalismo feminista: reflexões sobre o direito à igualdade de gênero. (Dissertação de Mestrado). Programa de Pós-Graduação em Direito. Universidade do Estado do Rio de Janeiro, Rio de Janeiro, 2016.

SOUZA NETO, Cláudio. SARMENTO, Daniel. Direito Constitucional: Teoria, história e métodos de trabalho. Belo Horizonte: Fórum, 2012.

TAYLOR, Charles. The Ethics of Authenticity. Cambridge: Harvard University, 1991. 
The Politics of Recognition. In: TAYLOR, C. Multiculturalism. New Jersey: Princeton University Press, 1994.

VIZIOLI, Luca; ROUSSELET, Guillaume A.; CALDARA, Roberto. Neural repetition suppression to identity is abolished by other-race faces. Proceedings of the National Academy of Sciences of the United States of America. Vol. 107, n. 46, 2010. Disponível em < http://www.pnas.org/content/107/46/20081.abstract>. Acesso em 20 mar 2017.

YOUNG, Iris Marion. Justice and the Politics of Difference. New Jersey: Princeton University Press, 1990

Enviado em: 19/05/2017

Aprovado em: 16/07/2017 